\title{
Effect of the feeding level during rearing on performance of Large White gilts. Part 2: effect on metabolite profiles during gestation and lactation, and on glucose tolerance
}

\author{
Yannick Le Cozler ${ }^{\mathrm{a}}$, Crystèle David ${ }^{\mathrm{b}}$, Valérie Beaumal ${ }^{\mathrm{b}}$, \\ Sigurd Johansen ${ }^{\mathrm{a}}$, Jean-Yves Dourmad ${ }^{\mathrm{b} *}$ \\ ${ }^{a}$ Centre for Reproductive Biology, Swedish University of Agricultural Sciences, \\ Department of Animal Nutrition and Management, Funbo-Lövsta, 75597 Uppsala, Sweden \\ ${ }^{\mathrm{b}}$ Station de recherches porcines, Inra, 35590 Saint-Gilles, France
}

(Received 12 January 1998; accepted 26 June 1998)

\begin{abstract}
Eighteen primiparous Large White sows were selected on d 104 of gestation. Animals had either high (AP) or reduced (R) level of body fatness, as a result of different feeding levels during rearing. A jugular catheter was surgically implanted under general anaesthesia and regular blood sampling, glucose tolerance and meal tests were performed. Plasma concentrations of insulin, glucose, urea, non-esterified fatty acids (NEFA), phosphorus and calcium were determined by radio-immune assay or enzymatic assay. Plasma concentration of urea increased with the progress of lactation, whereas NEFA decreased. Results of glucose tolerance and test meals suggested that animals with greater body reserves at farrowing were less tolerant to glucose than the lean ones. In addition, the higher NEFA level observed in AP animals also suggested that the level of body fatness at farrowing might be involved in the regulation of feed intake during lactation and could partially explain the lower spontaneous feed intake observed in these animals. @ Inra/Elsevier, Paris
\end{abstract}

sows / body fat / metabolites / lactation / glucose tolerance

Résumé - Effet du niveau d'alimentation pendant la croissance sur les performances de truies Large White primipares. Deuxième partie : évolution des paramètres sanguins en fin de gestation, au cours de la lactation et lors de tests de tolérance au glucose et de repas tests. Dix-huit truies primipares Large White ont été sélectionnées à $104 \mathrm{j}$ de gestation. Les animaux différaient par l'état de leurs réserves corporelles, soit importantes (AP), soit réduites $(\mathrm{R})$, à la suite de niveaux d'alimentation différents pratiqués pendant la période de croissance ( $28 \mathrm{~kg}$ - saillie). Un cathéter jugulaire

\footnotetext{
* Correspondence and reprints

E-mail: dourmad@st-gilles.rennes.inra.fr
} 
était placé sous anesthésie générale afin de réaliser des prélèvements sanguins hebdomadaires, des tests de tolérance au glucose et des repas tests. Les niveaux plasmatiques d'insuline, de glucose, d'acides gras non estérifiés (AGNE), d'urée, de phosphore et de calcium ont été déterminés, soit par des dosages radio-immunologiques, soit par des méthodes enzymatiques. Le niveau plasmatique d'urée augmentait au cours de la lactation, tandis que celui des AGNE tendait à diminuer. Les résultats des tests de tolérance au glucose et des repas tests suggèrent une tolérance moindre au glucose chez les animaux ayant plus de réserves corporelles à la mise bas. Le taux d'AGNE circulant plus élevé chez les animaux AP laisse supposer que le niveau des réserves corporelles à la mise bas pourrait être impliqué dans la régulation de la prise alimentaire pendant la lactation et pourrait aussi expliquer en partie la plus faible ingestion d'aliment observée chez ces animaux. (O Inra/Elsevier, Paris

truies / adiposité / métabolites / lactation / tolérance au glucose

\section{INTRODUCTION}

Nutritional requirements of lactating sows depend mainly on their milk production [17]. In practice, because feed intake during lactation is generally too low to meet the requirements, sows lose body weight and backfat and this has been associated with reproductive disorders at weaning $[12,20]$. A negative correlation between feed intake during gestation and feed intake during subsequent lactation has been reported in many studies $[3,5,27]$. Similarly, we observed a negative correlation between feeding level during rearing and ad libitum feed intake during lactation [16]. It has been suggested that the level of the body fatness at farrowing could play a major role in the variation of feed intake during lactation $[6,14,28]$.

During gestation, physiological modifications occur, such as the increase of the uterine blood flow, in order to convey the nutrients required for the development of foetuses [18]. Similar to women [8], sows have also been reported to become less tolerant to glucose and to have diabetic tendencies with the progress of gestation $[2,7,23]$. Bouillon Hausman et al. [2] noted that pregnant sows fed ad libitum were less tolerant to glucose compared to those fed restrictedly. Recently, glucose tolerance has been reported to be closely connected with piglet mortality [11] and with feed intake during gestation [29]. And, according to Weldon et al. [27], postpartum hypophagia obser- ved in sows fed ad libitum during gestation would be related to a reduced glucose tolerance and insulin resistance.

The aim of the present work was to study the effect of the feeding level during rearing, with the concomitant changes in body reserves at service, on 1) the concentrations of circulating metabolites during late gestation and during lactation, 2) the glucose tolerance in late gestation and mid-lactation.

\section{MATERIALS AND METHODS}

\subsection{Animals and feeding treatment}

At $28 \mathrm{~kg}$ live weight and 72 days of age on average, purebred Large White gilts were selected according to their body weight and general conformation. The experiment comprised three replicates from January to May 1995. Animals were housed in groups of 4-5 per pen, with individual stalls where they were kept only when they were fed. Half of the females were fed to appetite (AP) twice a day for $1 \mathrm{~h}$ each time, whereas the other half $(\mathrm{R})$ received $80 \%$ of the intake of AP gilts from the same replicate, at the same body weight. Females were fed at 0900 and 1500 hours, and the feed consumption of the AP females was recorded each day. All gilts received the same standard rearing diet (13.4 MJ digestible energy (DE) per kg; $18.1 \%$ crude protein (CP); $0.96 \%$ lysine). After service, gilts received individually $2.6 \mathrm{~kg} / \mathrm{d}$ of a standard gestation diet (12.6 MJ DE/kg; $13.9 \% \mathrm{CP} ; 0.59 \%$ lysine). The day of expected parturition, all females received $1 \mathrm{~kg}$ of feed at 0900 hours. After farrowing, they received a standard lactation diet (13.1 MJ DE/kg; $17.1 \% \mathrm{CP} ; 0.90 \%$ 
lysine). The level of feeding was progressively increased to reach ad libitum from d 5 post-farrowing. From weaning until the end of the experiment, $14 \mathrm{~d}$ after weaning, animals received $4.2 \mathrm{~kg} / \mathrm{d}$ of the gestation diet. Piglets received no creep feed during the experiment and were weaned after three weeks of lactation $(22 \pm 0.5 \mathrm{~d})$.

\subsection{Oestrus and farrowing synchronisation}

From d 260, oestrus cycles were synchronised with oral administration of allyl-trenbolone (Regumate ${ }^{\circledR}$, Roussel-Uclaf, France), as a daily dose of $20 \mathrm{mg}$ as a top dressing on the feed for $18 \mathrm{~d}$. Two weeks before the expected parturition, the gilts were individually penned, in farrowing crates $(1.9 \times 2.6 \mathrm{~m})$, on concrete floor with straw bedding. Parturition was induced at $114 \mathrm{~d}$ post-insemination, by a single intra-muscular injection of $2 \mathrm{~mL}$ cloprostenol at $\mathrm{d} 113$ of gestation (Planate ${ }^{\circledR}$, Pitman-Moore, USA). A myorelaxant (Monzal ${ }^{\circledR}$, Boehringer Ingelheim, Germany) and oxytocin (Rhône Merrieux, France) were used when farrowing started to stimulate contractions and facilitate the deliverance of the piglets. Supervision of piglet birth and gilts behaviour was provided during parturition. Litters were standardised to 11 piglets within $48 \mathrm{~h}$ of birth, using fostered piglets if necessary.

A full description of animal management and diet compositions has been given by Le Cozler et al. [14].

\subsection{Animal selection}

Within each of the three batches, six gilts (three from AP treatment and three from R treatment) were selected at the end of gestation. Selection was based on body weight (BW), backfat thickness $(\mathrm{BF})$, legs conformation and day of service. Extreme animals in $\mathrm{BW}$ and $\mathrm{BF}$ were excluded of the selection, but no difference at farrowing in the average BW and BF was observed between selected and non-selected animals $(241 \mathrm{~kg}$ and $21 \mathrm{~mm})$.

\subsection{Operation and weekly blood sampling}

On day 104 of gestation, an indwelling Silastic $^{(B)}$ (Dow Corning, Midland, MI, USA) catheter was surgically implanted into one of the jugular veins of the gilts under general anaesthesia and exteriorised on the dorsal side of the neck. Catheters were rinsed every $2 \mathrm{~d}$, with a $10-\mathrm{mL}$ saline solution $(0.9 \% \mathrm{NaCl})$ containing heparin and antibiotics. Blood samples were regularly collected at 1100 hours for glucose, insulin, nonesterified fatty acids (NEFA), urea, phosphorus and calcium determination. Values were recorded in relation to the parturition date $( \pm 0.5)(\mathrm{d}-5,0$, $+5,+10,+20$ and +27$)$. Blood samples were collected into heparinised tubes $(20 \mu \mathrm{L}$ of 5000 $\mathrm{IU} / \mathrm{mL}$ of heparin per tube) and centrifuged at $2500 \mathrm{rpm}$ for $10 \mathrm{~min}$. After centrifugation, the plasma was stored at $-20^{\circ} \mathrm{C}$ until assay.

\subsection{Glucose tolerance and meal tests}

Glucose tolerance tests were performed on d 106 of gestation and d 13 of lactation. After a 17-h fast, $0.5 \mathrm{~g}$ of glucose per $\mathrm{kg}$ of body weight (30\% glucose anhydride, Braun ${ }^{\circledR}$, Boulogne, France) was injected intravenously through the jugular catheter. The injection was followed by an injection of $20 \mathrm{~mL}$ of a saline solution $(0.9 \%$ $\mathrm{NaCl}$ ) containing $100 \mathrm{IU}$ heparin $/ \mathrm{mL}$. Minute zero was defined as the time at the end of glucose infusion. Blood samples were collected at -45 , $-15,0,5,10,15,20,25,30,35,40,50,60,70$, 80,90 and $120 \mathrm{~min}$.

Test meals were performed on d 108 of gestation and d 15 of lactation. After a 17-h fast, gilts received $1.6 \mathrm{~kg}$ of the lactation diet. The duration of the meal was recorded and any feed refusals were removed and weighed $30 \mathrm{~min}$ after the start of the test, if necessary. Blood samples were collected at $-30,-15,0,15,30,45,60,75$, $90,105,120,135,150,165$ and $180 \mathrm{~min}$. Minute zero was defined as the time of the blood sampling which was performed just following the meal deliverance.

During tolerance and test meals blood samples were collected and treated as previously described for the regular samples.

\subsection{Chemical analyses}

Automated enzymatic methods using a Cobas Mira multichannel analyser (Roche, Basel, Switzerland) were performed to determine concentrations of glucose, phosphorus, calcium (bioMerrieux kits ref 61273, 61571, 61041; Marcy l'Etoile, France), NEFA (Wako Chemical NEFA C; Unipath, Dardilly, France), and urea (Urea unimate 5, ref. 07-3685-6; Roche, Neuilly-sur-Seine, France). The intra-assay CV were $1.7 \%$ for a 
$880 \mathrm{mg} / \mathrm{L}$ sample of glucose, $3.4 \%$ for a $436 \mathrm{mg} / \mathrm{L}$ sample of phosphorus, $3.2 \%$ for a $110 \mathrm{mg} / \mathrm{L}$ sample of calcium and $2 \%$ for a $436 \mathrm{mg} / \mathrm{L}$ of urea. The inter-assay CV were $5.6 \%$ for a $880 \mathrm{mg} / \mathrm{L}$ sample of glucose, 6.9 and $11.6 \%$ for a 80 and a $50 \mathrm{mg} / \mathrm{L}$ sample of phosphorus, respectively, $13.7 \%$ for a $108 \mathrm{mg} / \mathrm{L}$ sample of calcium and $7.7 \%$ for a $387 \mathrm{mg} / \mathrm{L}$ sample of urea.

Plasma levels of insulin were measured with a validated RIA method [19]. Sensitivity was $3 \mu \mathrm{IU} / \mathrm{mL}$. Intra-assay CV of 10,6 and $7 \%$ and inter-assay CV of 14,19 and $24 \%$ were obtained from pool samples containing 3.8, 63.6 and $263.3 \mu \mathrm{IU} / \mathrm{mL}$ of insulin.

\subsection{Calculations and statistical analysis}

Data on daily samples were analysed by split plot analyses, using the GLM procedures of SAS [21]. The model tested the effect of treatment during rearing against effect of animal nested within treatment as error term, whereas the effect of day of sampling and the interaction of the day of sampling with treatment were tested against the residual error of the model, according to the SAS [21] specifications for repeated measures analysis. Significant interactions being observed, effect of feeding treatment was also tested within day of sampling, and the effect of day of sampling was analysed within treatment.

For glucose tolerance tests, the half life of the injected glucose and maximum increase in glycaemia were determined using the NLIN procedures of SAS [21]. For each treatment, the following model was used:

$\mathrm{X}_{\mathrm{ti}}=\mathrm{X}_{\mathrm{pi}}+\mathrm{X}_{\text {MAXi }} \mathrm{e}^{-b t i+}+\mathrm{X}_{\mathrm{di}}$, where $\mathrm{i}=$ treat ment (AP or $\mathrm{R}$ ), $\mathrm{X}_{\mathrm{ti}}=$ glucose concentration at $\mathrm{t}_{\mathrm{i}}$, $\mathrm{X}_{\mathrm{pi}}=$ pre-test concentration of glucose, $\mathrm{X}_{\mathrm{MAXi}}=$ the maximal increase in glucose concentration immediately after the infusion, $X_{\mathrm{di}}$, the difference between initial and asymptotic concentrations of glucose, $t_{i}=$ time $(\mathrm{min})$ relative to the end of the pulse dose of glucose $\left(0<t_{i}<60\right)$. Ordinary least square estimates of parameters were obtained using the Marquardt iterative method with a convergence criterion of $10^{-8}$. Parameter estimates were compared between treatments using the extra sum of squares principle. A full description of the method used was given by Van Milgen et al. [26].

Data on glucose, insulin, NEFA, lactate and urea concentrations before the test (meal or glucose tolerance); $1 \mathrm{~h}$ after the beginning of the test; $2 \mathrm{~h}$ after the beginning of meal in the case of the test meal; $3 \mathrm{~h}$ after the infusion in case of glucose tolerance test were analysed. A numeric expression for glucose tolerance was obtained by integrating the glucose concentration curves from glucose tolerance tests over 0-120 min using fasting levels as base line. The incremental insulin area was calculated by integrating the hormone concentration curve. The calculations were performed by an interpolation of the evolution of glycaemia or insulinemia concentrations between two consecutive points. Maximum increases in glucose and insulin concentrations, and the corresponding times needed to reach these maximal values during the tests meal, were determined. Data were analysed by split plot analyses, using the GLM procedures of SAS [21]. The model tested the effect of treatment during rearing against the effect of animal within treatment, whereas the effect of sampling day and the interaction of sampling day with treatment were tested against the error of the model. When significant interactions were found, the effect of treatment within stage was tested.

The evolution of the concentrations of glucose, insulin and NEFA immediately after the start of meal and glucose tolerance tests were analysed using multivariate analysis with repeated measure analysis of variance, because the concentrations of glucose, insulin and NEFA were interrelated. Concentrations of glucose, insulin and NEFA were dependant variables and treatment during rearing was the independent variable. A repeated statement for time was included and basal concentrations were used as a covariable.

\section{RESULTS}

A total of 17 gilts of the 18 initially selected were used in the final calculations. One of the AP gilts was sick during lactation. Most of the gilts farrowed on d 114 of gestation $(85 \%)$ and average gestation length was $114( \pm 0.5)$ days.

\subsection{Weekly sampling}

The concentrations of plasma metabolites at $d-5,0,+5,+10,+20$ and +27 relative to parturition are summarised in table $I$. 


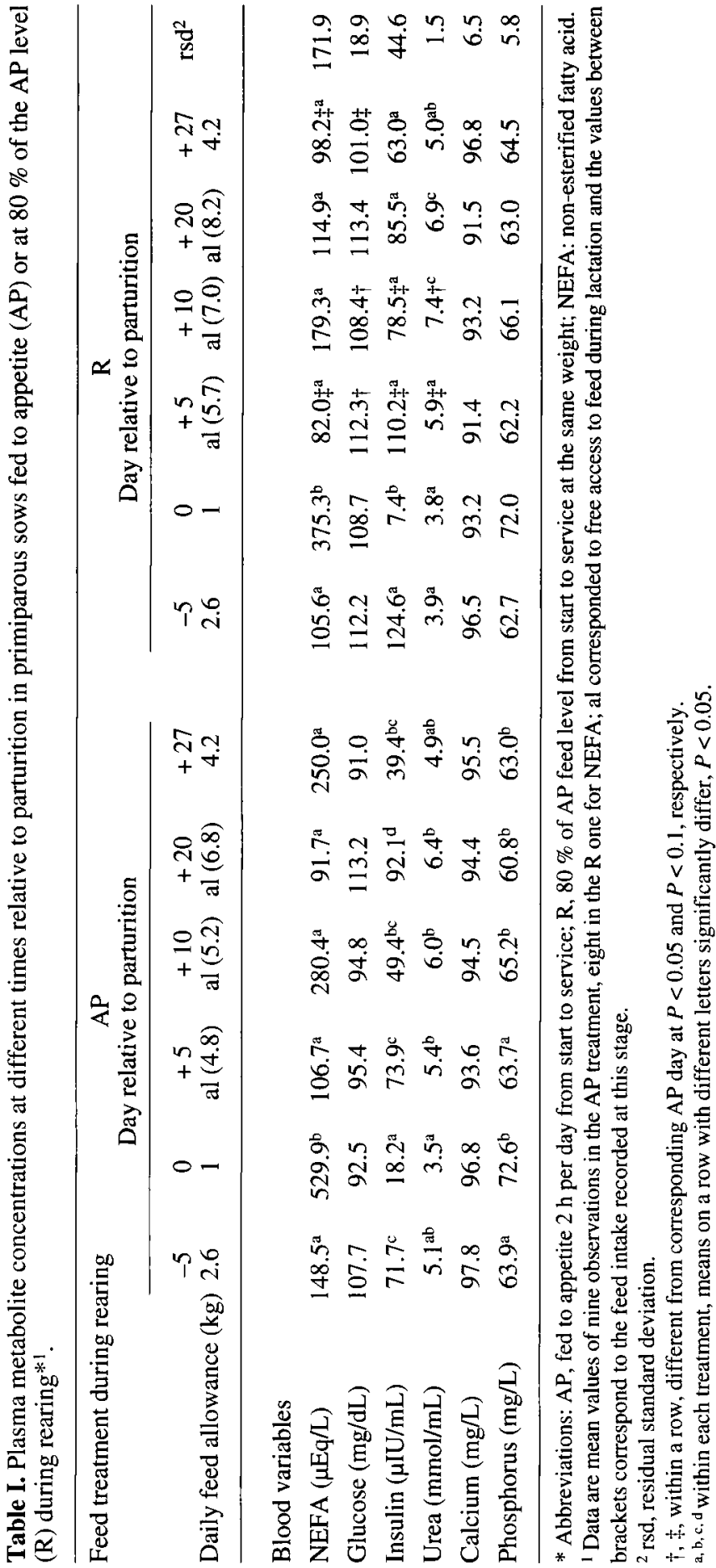


Concentration of calcium was not affected by the day of sampling or the feeding treatment during rearing $(94.6 \pm 6.5 \mathrm{mg} / \mathrm{L})$. Level of phosphorus was significantly higher by about $10 \mathrm{mg} / \mathrm{L}$ the day of parturition than it was either before or after farrowing in $\mathrm{AP}$ sows, whereas no statistical difference was observed in $\mathrm{R}$ gilts. Plasma concentration of NEFA was significantly higher at parturition than during the pre- or post-partum periods in the two treatments (table I).
During lactation, NEFA level reached a maximal value on $d+10$, but no significant effect of lactation day was observed. Concentration of urea increased during lactation and decreased after weaning to reach similar values to those observed at the end of gestation (table I). Insulin level was significantly lower during parturition than at the end of gestation $(d-5)$ or during the rest of experiment $(\mathrm{d}+5$ to $\mathrm{d}+27)$.

Table II. Mean values ( \pm s.e.m.) of plasma metabolite concentrations during glucose tolerance tests*.

\begin{tabular}{|c|c|c|c|c|c|c|c|}
\hline \multirow[t]{2}{*}{ Item } & \multicolumn{2}{|c|}{ Gestation (d 106) } & \multicolumn{2}{|c|}{ Lactation (d 13) } & \multicolumn{3}{|c|}{ Statistical significance } \\
\hline & AP & $\mathrm{R}$ & AP & $\mathrm{R}$ & $\mathrm{T}$ & $\mathrm{S}$ & $\mathrm{T}^{*} \mathrm{~S}$ \\
\hline \multicolumn{8}{|c|}{ Total area under the curve between 0 and $120 \mathrm{~min}$} \\
\hline Insulin ${ }^{1}$ & $4.6 \pm 0.8$ & $3.9 \pm 0.8$ & $5.4 \pm 1.2$ & $4.0 \pm 0.7$ & $\mathrm{~ns}$ & $\mathrm{~ns}$ & ns \\
\hline Glucose $^{2}$ & $4190 \pm 820$ & $4740 \pm 770$ & $8980 \pm 1480$ & $6130 \pm 770$ & ns & $* *$ & ns \\
\hline \multicolumn{8}{|c|}{ Max increase in insulin ${ }^{5}$} \\
\hline & $175.0 \pm 22.8$ & $143.1 \pm 26.1$ & $144.0 \pm 27.3$ & $126.8 \pm 22.8$ & $\dagger$ & ns & ns \\
\hline Time $(\min )^{3}$ & $17.5 \pm 2.5$ & $21.9 \pm 2.7$ & $16.3 \pm 2.5$ & $19.4 \pm 1.0$ & $\dagger$ & ns & ns \\
\hline \multicolumn{8}{|c|}{ Pre-test value of } \\
\hline Glucose $^{4}$ & $88.4 \pm 2.9$ & $94.0 \pm 3.9$ & $61.9 \pm 3.3$ & $67.3 \pm 3.9$ & ns & $* * *$ & ns \\
\hline Insulin 5 & $10.8 \pm 1.8$ & $11.1 \pm 3.4$ & $3.0 \pm 0.3$ & $3.0 \pm 0.3$ & ns & $* * *$ & ns \\
\hline Urea $^{6}$ & $3.9 \pm 0.3$ & $4.2 \pm 0.4$ & $6.0 \pm 0.6$ & $7.3 \pm 0.4$ & $*$ & $* * *$ & ns \\
\hline $\mathrm{NEFA}^{7}$ & $270 \pm 31$ & $266 \pm 28$ & $1470 \pm 40$ & $1156 \pm 60$ & ns & $* * *$ & ns \\
\hline \multicolumn{8}{|c|}{ Value at $60 \mathrm{~min}$ of } \\
\hline Glucose & $71.8 \pm 5.5$ & $72.6 \pm 5.8$ & $106.0 \pm 12.0 \mathrm{a}$ & $69.7 \pm 7.2 b$ & $\dagger$ & ns & $*$ \\
\hline Insulin & $12.9 \pm 3.0$ & $15.4 \pm 5.2$ & $25.7 \pm 8.3 \mathrm{a}$ & $6.7 \pm 0.9 \mathrm{~b}$ & $\dagger$ & ns & $*$ \\
\hline Urea & $3.6 \pm 0.3$ & $4.0 \pm 0.4$ & $5.8 \pm 0.4$ & $6.9 \pm 0.3$ & $*$ & $* * *$ & ns \\
\hline NEFA & $163 \pm 38$ & $95 \pm 12$ & $594 \pm 133$ & $416 \pm 99.1$ & ns & $* * *$ & ns \\
\hline \multicolumn{8}{|c|}{ Value at $120 \mathrm{~min}$ of } \\
\hline Glucose & $81.1 \pm 3.6$ & $83.3 \pm 4.1$ & $52.9 \pm 4.0$ & $58.6 \pm 7.2$ & ns & $* * *$ & ns \\
\hline Insulin & $7.3 \pm 1.5$ & $8.4 \pm 4.5$ & $3.7 \pm 0.6$ & $2.6 \pm 0.3$ & ns & $\dagger$ & ns \\
\hline Urea & $3.6 \pm 0.3$ & $4.1 \pm 0.4$ & $5.9 \pm 0.5$ & $5.0 \pm 0.4$ & $*$ & $* * *$ & $\mathrm{~ns}$ \\
\hline NEFA & $572 \pm 78$ & $419 \pm 99$ & $1372 \pm 177$ & $1424 \pm 134$ & ns & $* * *$ & ns \\
\hline
\end{tabular}

*Abbreviations: see table $I$; T: feed treatment during rearing; $\mathrm{S}$ : stage of experiment (gestation or lactation); $\mathrm{T} * \mathrm{~S}$ : interaction between stage and treatment.

Statistical significance: ${ }^{* * *}: P<0.001$; $*: P<0.01 ; *: P<0.05 ; \uparrow: P<0.1$; ns: $P>0.1$; within a row, means with different superscript letters significantly differ at $P<0.05$.

${ }^{1}$ Per $10^{3} \mu \mathrm{IU}^{-1} \mathrm{~mL}^{-1} \mathrm{~min}{ }^{2}$ per $\mathrm{mg}^{-1} \mathrm{dL}^{-1} \mathrm{~min}$.

${ }^{3}$ Time to reach the maximal value.

${ }^{4}$ Per $\mathrm{mg} / \mathrm{dL} ;{ }^{5}$ per $\mu \mathrm{IU} / \mathrm{mL} ;{ }^{6}$ per $\mathrm{mmol} / \mathrm{mL} ;{ }^{7}$ per $\mu \mathrm{Eq} / \mathrm{L}$. 
No difference in metabolite levels among treatments was observed at $\mathrm{d}-5$ or d 0 (table $I$ ). At $\mathrm{d}+5$, plasma levels of glucose and insulin were higher $(P<0.05)$ in the $\mathrm{R}$ gilts than in the AP ones, by 15 and $41 \%$, respectively, whereas the level of NEFA was lower by $9 \%(P<0.1)$. At $d+10$, urea was $1.4 \mathrm{mmol} / \mathrm{mL}$ higher in the $\mathrm{R}$ gilts than in the AP females $(P<0.05)$. No effect of treatment was observed at the end of lactation $(d+20)$, whereas, after weaning $(d+27)$, the glucose concentration was higher and the NEFA level tended to be lower in the $\mathrm{R}$ gilts than in the AP ones $(P<0.1)$.

\subsection{Glucose tolerance tests}

Concentrations of glucose, insulin, NEFA and urea before the test were significantly different in gestation and in lactation, $+26.5 \mathrm{mg} / \mathrm{dL},+7.9 \mu \mathrm{IU} / \mathrm{mL},-1036$ $\mu \mathrm{Eq} / \mathrm{L}$ and $-2.7 \mathrm{mmol} / \mathrm{L}$, respectively (table $I I$ ). Only the urea level was affected by rearing treatment. It was higher in $\mathrm{R}$ gilts than in AP ones, by $0.8 \mathrm{mmol} / \mathrm{L}(P<0.05)$.

Profiles of glucose, insulin and NEFA during glucose tolerance tests are presented in figure 1 . Immediately after the infusion of glucose, the plasma level of glucose increased, and reached values of 491 and $402 \mathrm{mg} / \mathrm{dL}$ in gestation and lactation, respectively. Insulinemia also increased immediately after infusion, and reached its maximal value $18 \mathrm{~min}$ later (figure $1 \mathrm{~b}, e$ ). One hour after the infusion of glucose, the glucose level was significantly higher during lactation than during gestation in the AP gilts, whereas $120 \mathrm{~min}$ after the infusion, it was lower during lactation than during gestation in both treatments $(P<0.05)$. The area under the insulin curve was not affected by physiological state, but the area under the glucose curve was higher during lactation than during gestation $(P<0.01)$. Immediately after the injection of glucose, NEFA decreased in gestation and lactation (figure 1 $c, f$ ). One hour after the infusion of glucose, urea and NEFA levels were significantly higher during lactation than during gestation. After $120 \mathrm{~min}$, urea and NEFA levels were still significantly higher in lactation than in gestation (table $I$ ).

No effect of treatment during rearing was observed for most of the parameters, but a tendency (table $I I, P<0.1$ ) to reach later the maximal insulin concentration value was observed in the R gilts than in the AP (20.6 and $16.9 \mathrm{~min}$, respectively). The half-life of glucose was not different during gestation between treatments (figure $1 a, e$ ), but tended to be higher during lactation for the AP gilts than for the R ones (18.9 and 13.5 min, respectively; $P<0.1$ ). During lactation, glucose levels were significantly higher from 20 to $80 \mathrm{~min}$ after the injection of glucose in the AP gilts (figure $1 d$ ). No effect of treatment on glucose or insulin levels was observed, when expressed by the area under the curves (table $I I$ ), but NEFA concentrations in gestation and lactation (figure $l c, f$ ) were higher in the AP gilts than in the R ones $(P<0.05)$.

\subsection{Test meals}

No differences between treatment and stage of experiment were observed for the duration of the test meals $(14.8 \pm 7.3 \mathrm{~min})$. The test meals were performed $2 \mathrm{~d}$ after the glucose tolerance tests. Similar effects of treatment or physiological state as during tolerance test were observed for the pre-test values for most of the metabolites and consequently, were not presented in table III.

Glycaemia and insulinemia increased and reached their maximal value 1-h after the beginning of the meal (table III). No effect of stage of experiment or treatment was observed on the time needed to reach the maximal values. Maximal values of glucose and insulin were significantly higher during lactation than during gestation (by $28.6 \mathrm{mg} / \mathrm{dL}$ and $82.0 \mu \mathrm{IU} / \mathrm{mL}$, respectively; table III). One hour after the beginning of 


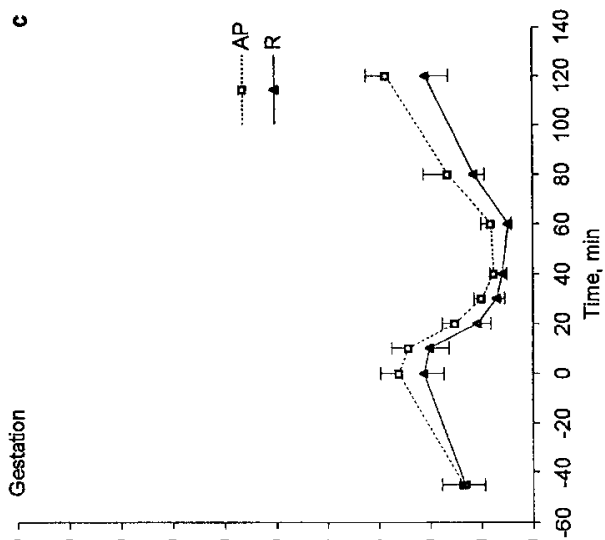

㞭 总
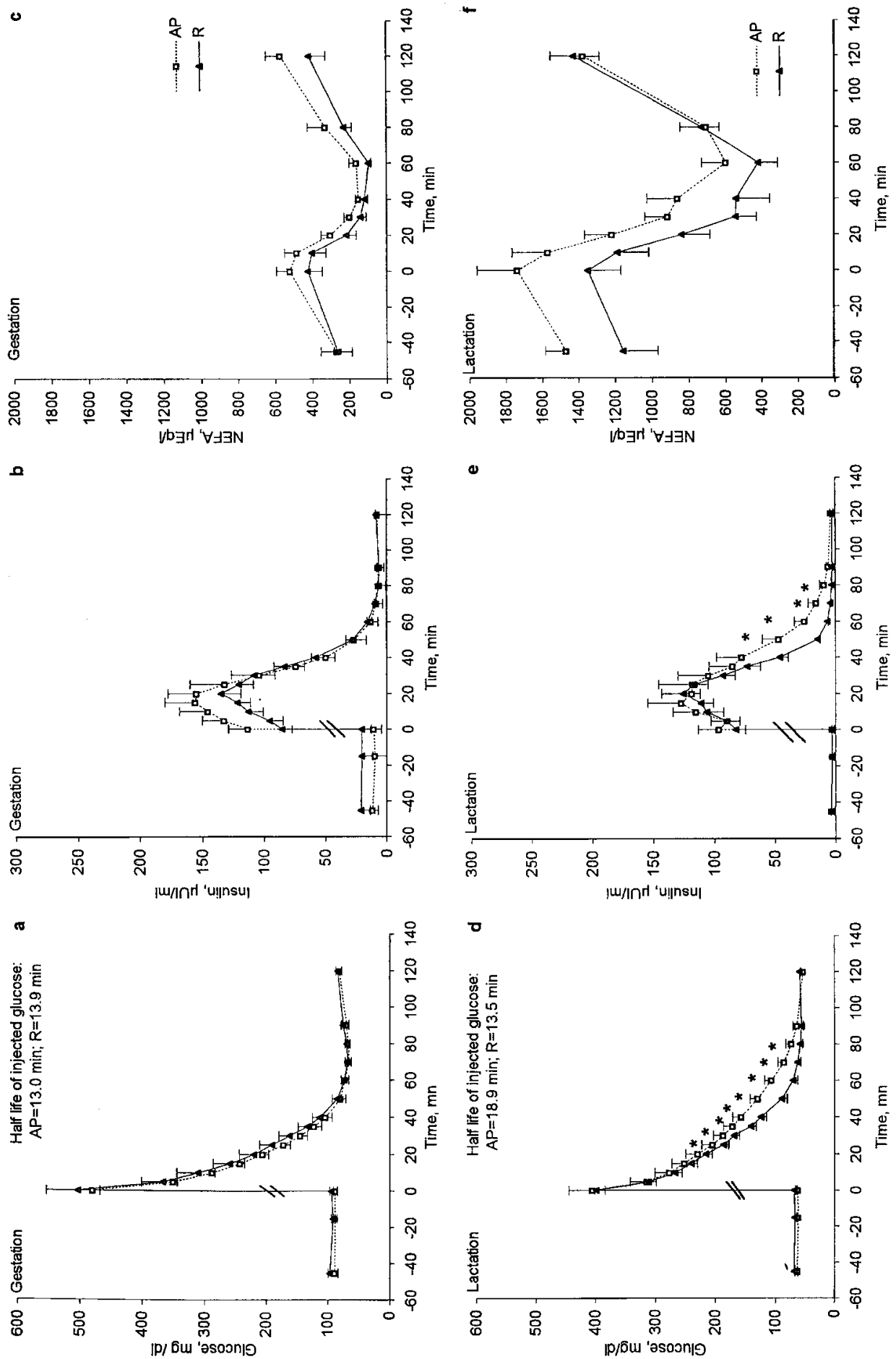
the meal, urea concentration was significantly higher during lactation than during gestation, and glucose and NEFA levels tended to be higher during lactation than during gestation $(P<0.1)$. Three hours after the test, levels of glucose and insulin remained higher than before the test, whereas concentrations of urea and NEFA were lower (table III; figure $2 a, f$ ). Urea remained significantly higher during lactation than during

Table III. Mean values ( \pm s.e.m.) of plasma metabolite concentrations during test meals*.

\begin{tabular}{|c|c|c|c|c|c|c|c|}
\hline \multirow[t]{2}{*}{ Item } & \multicolumn{2}{|c|}{ Gestation (d 108) } & \multicolumn{2}{|c|}{ Lactation (d 15) } & \multicolumn{3}{|c|}{ Statistical significanc } \\
\hline & AP & $\mathbf{R}$ & AP & $\mathrm{R}$ & $\mathrm{T}$ & $S$ & $T^{*} \mathrm{~S}$ \\
\hline \multicolumn{8}{|c|}{ Total area under the curve, between 0 and $180 \mathrm{~min}$} \\
\hline Insulin ${ }^{1}$ & $8.5 \pm 1.2$ & $12.8 \pm 2.7$ & $17.1 \pm 2.2$ & $18.0 \pm 3.3$ & ns & $* *$ & ns \\
\hline Glucose $^{2}$ & $2830 \pm 41$ & $4200 \pm 75$ & $9250 \pm 13$ & $7570 \pm 16$ & ns & $* * *$ & ns \\
\hline \multicolumn{8}{|c|}{ Max increase in } \\
\hline Insulin & $134.3 \pm 26.0$ & $212.8 \pm 43.6$ & $246.2 \pm 25.6$ & $268.4 \pm 56.9$ & ns & * & ns \\
\hline Glucose & $128.9 \pm 5.6$ & $140.2 \pm 6.8$ & $175.4 \pm 13.4$ & $160.6 \pm 12.1$ & ns & $* *$ & ns \\
\hline \multicolumn{8}{|l|}{ Time $(\min )^{3}$} \\
\hline Insulin & $66.4 \pm 4.8$ & $70.0 \pm 5.0$ & $65.0 \pm 8.9$ & $60.0 \pm 8.3$ & ns & ns & ns \\
\hline Glucose & $57.5 \pm 7.7$ & $56.2 \pm 8.6$ & $60.2 \pm 5.6$ & $56.0 \pm 9.6$ & ns & ns & ns \\
\hline \multicolumn{8}{|c|}{ Value at $60 \mathrm{~min}$ of } \\
\hline Glucose & $114.4 \pm 6.0 \mathrm{a}$ & $132.7 \pm 5.9 b$ & $148.8 \pm 15.3$ & $144.1 \pm 15.2$ & $\dagger$ & $\dagger$ & ns \\
\hline Insulin & $123 \pm 29$ & $182 \pm 47$ & $181 \pm 37$ & $226 \pm 62$ & ns & ns & ns \\
\hline Urea & $2.8 \pm 0.2$ & $3.4 \pm 0.2$ & $5.9 \pm 0.8$ & $5.8 \pm 0.4$ & ns & $* * *$ & ns \\
\hline NEFA & $228 \pm 81$ & $154 \pm 38$ & $383 \pm 67$ & $176 \pm 31$ & $* *$ & + & ns \\
\hline \multicolumn{8}{|c|}{ Value at $180 \mathrm{~min}$ of } \\
\hline Glucose & $104.9 \pm 4.9$ & $107.2 \pm 3.4$ & $102.9 \pm 6.9$ & $93.8 \pm 6.5$ & ns & $\dagger$ & ns \\
\hline Insulin & $38.7 \pm 9.3$ & $34.3 \pm 8.5$ & $61.6 \pm 18.0$ & $40.8 \pm 12.2$ & ns & $\mathrm{ns}$ & $\mathrm{ns}$ \\
\hline Urea & $3.2 \pm 0.2$ & $3.9 \pm 0.2$ & $6.0 \pm 0.5$ & $5.4 \pm 0.3$ & ns & $* * *$ & ns \\
\hline NEFA & $198 \pm 38$ & $171 \pm 18$ & $288 \pm 68$ & $242 \pm 59$ & + & $\dagger$ & \\
\hline
\end{tabular}

*Abbreviations: see table I; T: feed treatment during rearing; S: stage of experiment (gestation or lactation); $\mathrm{T} * \mathrm{~S}$ : interaction between stage and treatment.*Abbreviations: see tables $I$ and $I I$.

Statistical significance: ***: $P<0.001$; **: $P<0.01 ; *: P<0.05$; $: P<0.1$; ns: $P>0.1$; within a row, means with different superscript letters significantly differ at $P<0.05$.

${ }^{1}$ Per $10^{3} \mu \mathrm{IU}^{-1} \mathrm{~mL}^{-1} \mathrm{~min} ;{ }^{2}$ per $\mathrm{mg}^{-1} \mathrm{dL}^{-1} \mathrm{~min}$.

${ }^{3}$ Time to reach the maximal value.

${ }^{4}$ Per $\mathrm{mg} / \mathrm{dL} ;{ }^{5}$ per $\mu \mathrm{IU} / \mathrm{mL} ;{ }^{6}$ per $\mathrm{mmol} / \mathrm{mL} ;{ }^{7}$ per $\mu \mathrm{Eq} / \mathrm{L}$.

Figure 1. Mean values $( \pm$ s.e.m.) for concentrations of plasma glucose $(a, d)$, insulin $(b, e)$ and nonesterified fatty acid (NEFA) (c, f) in gestation (G) or lactation (L) following an intravenous injection of $0.5 \mathrm{~g}$ of glucose per $\mathrm{kg}$ of body weight. Samples were performed before and immediately after the infusion. Half-life of infused glucose was not different between treatments during gestation, but was significantly higher for AP sows during lactation $(P<0.05)$. Effects of the stage of experiment ( $\mathrm{G}$ or L) and of the interaction between the stage of the experiment and the sampling time were observed for glucose and NEFA profiles $(P<0.05)$, whereas an effect of treatment was noted on NEFA concentrations $(P<0.05)$.

* For each profile, for each sampling time, concentrations of metabolites of the AP and R treatments differ, $P<0.05$. 

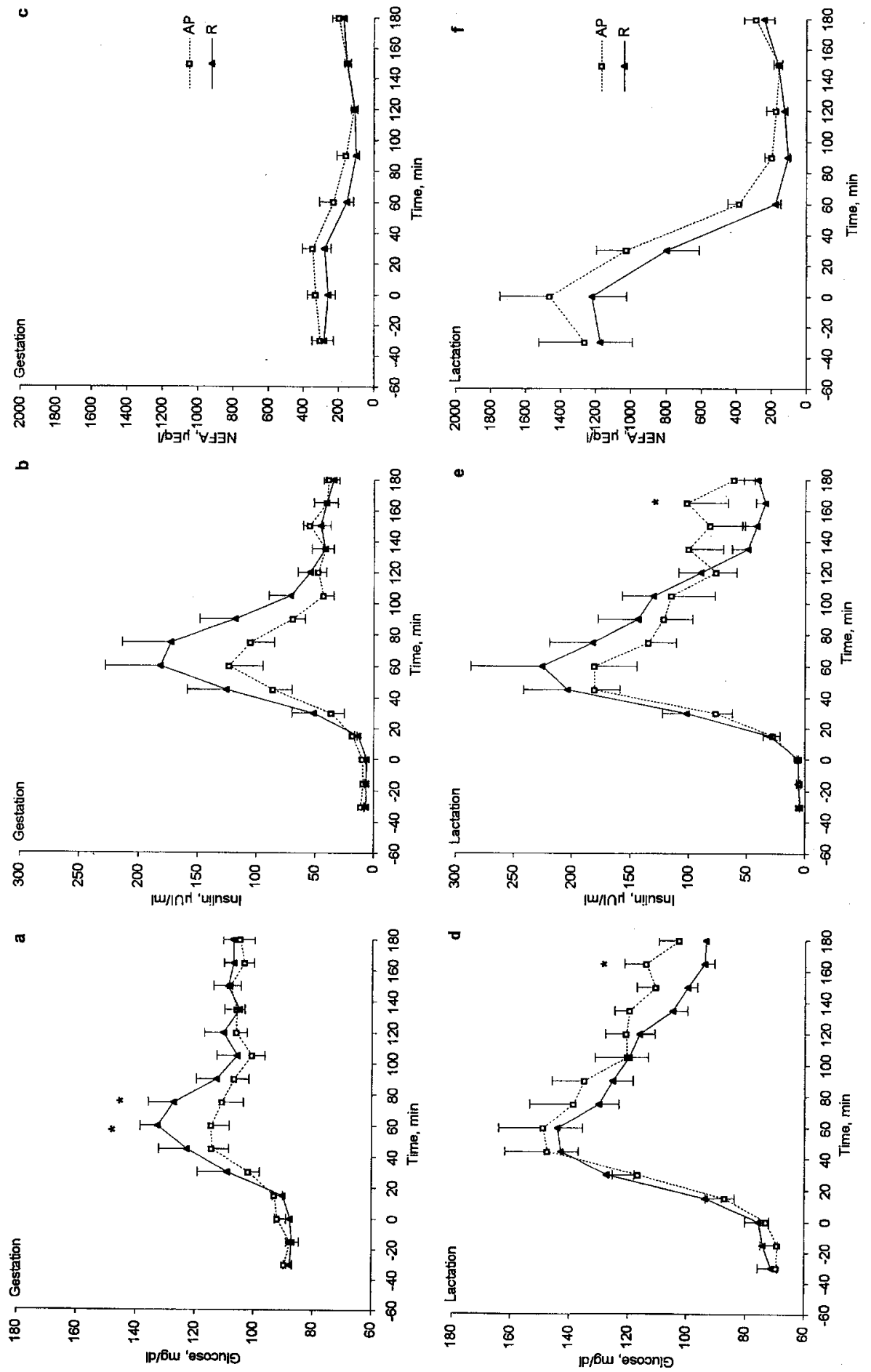
gestation and was not affected by rearing treatment. After the meal, a lower NEFA concentration was observed both during gestation and lactation in the $\mathrm{R}$ group $(P<0.1)$.

\section{DISCUSSION}

The results for NEFA concentrations in the weekly samples $(\mathrm{d}-5$ to +27 , table I) are in agreement with those obtained in other recent studies $[10,25,27]$. The highest concentration of NEFA at parturition was partially due to the lower feed allowance the day of farrowing, compared with that given before or after farrowing. But this phenomenon may be amplified by metabolic changes associated with lactogenesis and parturition [25]. When lactogenesis occurs, the adrenergic receptor population increases in the adipose tissue, resulting in an increase in epinephrine-stimulated fatty acid release, and, consequently, a higher concentration of circulating NEFA [4].

In contrast with our results, some authors have observed a linear decrease in plasma NEFA concentration with the progress of lactation [10, 25]. Trottier and Easter [25] suggested that both the increase in feed intake during lactation and the accelerated uptake of NEFA by the mammary gland might explain this evolution. In the present work, a higher concentration of NEFA was observed during the second week of lactation than during the first one. This was followed by a reduction during the third week of lactation, which agreed with the results of Weldon et al. [27] and Neil [16]. As growth hormone is known to be a catabolic hormone, the decrease in its plasma level during the third week of lactation observed by Schams et al. [22] may explain the decrease in NEFA at the end of lactation. Similarly, as IGF1 is known to act as an anabolic hormone for protein, its decrease during lactation, observed by Schams et al. [22], may explain the increase in urea level noted in the present work. The increase in urea level may reflect more pronounced protein losses at the end of lactation, but according to Neil [16], the high level in plasma urea could also reflect the fact that the dietary protein intake surpassed the actual requirements of the lactating sows. The differences in urea levels among treatment in the present work would then be the consequence of the higher feed intake in the $\mathrm{R}$ gilts compared to the AP ones [14].

In the present work, the concentrations of NEFA were lower at the beginning of lactation in the gilts restrictedly fed during rearing, and which, consequently, had lower body fat reserves at farrowing. Weldon et al. [27] also observed differences in NEFA levels during lactation in gilts fed different feeding levels during gestation. As litters were equalised at birth, the difference in NEFA levels between treatments could not be related to a different number of suckling piglets and consequently, to a different level of milk production, as proposed by Neil [16]. Thus, gilts from both treatments had similar nutritional demands, as illustrated by the similar growth of the litters [14]. It has been reported in cows that mobilisation of body fat during lactation occurs because the energy supplied by the daily feed intake is too low to meet the needs for milk production [15]. Bareille and Faverdin [1] suggested that body fat mobilisation in early

Figure 2. Mean values ( \pm s.e.m.) for concentrations of plasma glucose $(a, d)$, insulin $(b, e)$ and nonesterified fatty acid (NEFA) (c, f) in gestation or lactation following test meal. All animals received $1.6 \mathrm{~kg}$ feed after a $17-\mathrm{h}$ fast and samples were performed before and immediately after the meal delivery. Effect of stage (G or L) was observed for insulin and NEFA levels, whereas a significant interaction between the stage of experiment and the time of sampling was observed for all metabolites $(P$ $<0.05$ ).

* For each profile, for each sampling time, concentrations of metabolites of the AP and R treatments differ, $P<0.05$. 
lactation would be the initial phenomenon orchestrating a limitation of the daily feed intake in cows, by a direct metabolic inhibitory effect. The mechanisms involved in the negative relationship between feeding level during rearing and ad libitum feed intake during lactation would then be related to the lipostatic regulation of long-term feed intake (Kennedy, 1953, cited by Kissileff and Van Itallie [13]). Thus, similar to the suggestion of Dourmad [6], the body composition at farrowing could then explain most of the effects of the feeding level during rearing on metabolite profiles and feed intake during lactation. The higher concentration of NEFA during lactation in gilts fed ad libitum during rearing was more likely the result of higher body reserves at farrowing rather than that of the lower feed intake during lactation.

Plasma glucose and insulin concentrations the day of parturition were not affected by feeding treatment during rearing, probably because all animals received only $1 \mathrm{~kg}$ feed the morning of farrowing, following a 17-h fast. At $d+5$ and $d+10$, these concentrations of glucose and insulin tended to be lower in the fat gilts, which had been fed ad libitum during rearing, than in the thin ones. Similar results were observed in gilts receiving different levels of feed during gestation [27, 29]. Weldon et al. [27] demonstrated that regular injection of insulin is effective in increasing circulating concentration of insulin and in stimulating feed intake. According to these authors, the postpartum hypophagia observed in sows fed ad libitum during gestation is related to a reduced glucose tolerance and an insulin resistance. Thus this phenomenon would be related to the glucostatic regulation of shortterm feed intake first developed by Mayer (1955, cited by Kissileff and Van Itallie [13]), complementing the theory of the lipostatic regulation of long-term feed intake previously described.

The results from glucose tolerance tests gave more information on the possible dif- ferences in glucose tolerance and/or insulin resistance between gilts with different body reserves at service. The absence of difference between treatments for the peak value of glucose following the infusion confirmed that the amount of glucose infused provided similar initial concentrations of plasma glucose [29]. During the glucose tolerance test performed in lactation, the lower half life of glucose in gilts with low body reserves at farrowing suggested a better glucose tolerance in these females. This is in agreement with Weldon et al. [27], who observed similar effects of glucose tolerance during lactation in gilts fed restrictedly during gestation. At the end of gestation, the sensitivity of insulin release in response to glucose stimulation tended to be higher in the gilts with low reserves at service than in those with high body reserves, whereas no difference between treatments was observed in lactation. Insulin peaks were similar in both treatments after glucose infusion in lactation, but the decrease in insulin level happened faster in the gilts with low body reserves at service than in the other ones.

According to Weldon et al. [27], these prolonged high levels of glucose and insulin observed in fat animals might be explained either by an increase in the half life of insulin or by an increase in its secretion. In the present work, $1 \mathrm{~h}$ after the beginning of the glucose infusion during lactation, the insulin concentration was higher in the fat gilts. Similarly, the test meal performed during lactation confirmed that the levels of insulin tended to be higher 2 and $3 \mathrm{~h}$ after the start of the meal in the fat animals. But despite the fact that the glucose concentration seemed to be higher, no statistical difference was observed. The high persistence of glucose and insulin concentrations after a meal may then delay the onset of the ensuing meal and reduce the number of meals per day [27] and therefore, may reduce daily feed intake, as was observed in the present experiment [14]. Dourmad [6] also observed a reduction in daily feed intake during lactation in primiparous sows, which received 
different levels of feed during gestation, and this reduction was mostly the result of a reduction of meal size, rather than a decrease of the number of meals per day.

When glucose tolerance tests were performed in pregnant primiparous [29] or multiparous [7] sows, a difference in glucose tolerance was observed between animals with different fat reserves at the end of gestation. According to Xue et al. [29], the greater body fat reserves of sows fed a high energy level during pregnancy might impair their glucose tolerance and the sensitivity of their insulin release to glucose concentrations. In the present study, plasma level of glucose during gestation was not affected by rearing treatment after an infusion, but higher peaks of insulin were observed for fat gilts. This result suggested that more insulin had to be released for the same amount of infused glucose and consequently, these animals might be more resistant to insulin. Etienne et al. [7] observed a higher concentration of glucose during the entire gestation after a meal in sows fed a low level of feed during gestation, but these animals also had a lower level of circulating insulin. In the present work, the glucose concentration tended to be higher in lean gilts $1 \mathrm{~h}$ after the beginning of the test meal during gestation, suggesting a poor glucose tolerance.

The apparent difference between the results from the meal and glucose tolerance tests during gestation suggested that some differences in the physiology of the digestive tract of the animals reared differently may exist. Differences between an oral and intravenous infusion of glucose observed by Shuster et al. [24] in humans were also observed and may explain the differences observed in the present study. Shuster et al. [24] observed differences in concentrations of polypeptides and other digestive hormones between the two types of tests, that might influence insulin secretion. In pigs, regulation of feed intake is a combination of three different factors working largely in the duodenum: osmotic sensitivity, gluco- receptors and cholecystokinin [9]. Thus, possible differences in the digestive physiology, and in the regulation of the digestive peptides and hormones between fat and lean animals at farrowing may partially explain the differences observed between test results.

\section{Conclusion}

Restricting daily feed allowance to gilts during rearing produces animals with a lower fat content at farrowing. Fat sows at farrowing had higher plasma concentrations of nonesterified fatty acids and lower basic levels of insulin during lactation. They appeared to be less tolerant to glucose infusions and more resistant to insulin. After a test meal during lactation, higher plasma levels of glucose and insulin were observed in these animals. This could delay the onset of their next ensuring meal and/or its size. The differences observed between the concentration of substrates are probably responsible for the post-partum hypophagia observed in primiparous sow during lactation.

\section{ACKNOWLEDGEMENTS}

The authors gratefully thank Mr J. Van Milgen, for his help in the mathematical approach; Mr Y. Lebreton, J.C. Hulin, M. Massard, M. Lefebvre, J. Gauthier, G. Conseil, and all the staff at the Pig Research Station for taking care of the animals. They also wish to thank Drs H. Quesnel and M.C. Père from Inra, St-Gilles, France, for reading the manuscript.

\section{REFERENCES}

[1] Bareille N., Faverdin P., Lipid metabolism and intake behavior of dairy cows: effects of intravenous lipid and $\beta_{2}$-drenergic supplementation, J. Dairy Sci. 79 (1996) 1209-1220.

[2] Bouillon Hausman D., Kasser T.R., Seerley R., Martin R.J., Studies of gestational diabetes using the pig as a model, in: Tumbleson (Ed.), Swine in Biomedical Research (1), Plenum Press, New York and London, 1986, pp. 561-572.

[3] Brooks P.H., Feeding the reproductive female, Proc. Pig Vet. Soc. 9 (1982) 84-102. 
[4] Collier R.J., McNamara J.P., Wallace C.R. Dehoff M.H., A review of endocrine regulation of metabolism during lactation, J. Anim. Sci. 59 (1984) 498-510.

[5] Dourmad J.Y., Effect of feeding level in the gilt during pregnancy on voluntary feed intake during lactation and changes in body composition during gestation and lactation, Livest. Prod. Sci. 27 (1991) 309-319.

[6] Dourmad J.Y., Standing and feeding behaviour of the lactating sow: effect of feeding level during pregnancy, Appl. Anim. Behav. Sci. 37 (1993) 311-319.

[7] Etienne M., Père M.C., Dourmad J.Y., Adaptations du métabolisme glucidique chez la truie multipare. Effets de la gestation et du niveau d'alimentation, J. Rech. Porcine en France 29 (1997) 73-80.

[8] Hornnes P.J., Kühl C., Cortisol and glucose tolerance in normal pregnancy, Diabete and Metabolism 10 (1984) 1-6.

[9] Houpt T.R., Baldwin B.A., Houpt K.A., Effects of duodenal osmotic loads on spontaneous meals in pigs, Phys. Behav. 30 (1983) 787-796.

[10] Hultén F., Neil M., Einarsson S., Håkansson J., Energy metabolism during late gestation and lactation in primiparous sows in relation to backfat thickness and the interval from weaning to first oestrus, Acta Vet. Scand. 34 (1993) 9-20.

[11] Kemp B., Soode N.M., Vesseur P.C., Helmond F.A., Spoorenberg J.H., Frankena K., Glucose tolerance of pregnant sows is related to postnatal pig mortality, J. Anim. Sci. 74 (1996) 879-885.

[12] King R.H., Williams I.H., The effect of nutrition on the reproductive performance of first litter sows. 1 Feeding level during lactation and between weaning and mating, Anim. Prod. 38 (1984) 241-247

[13] Kissileff H.R., Van Itallie T.B., Physiology of the control of feed intake, Ann. Rev. Nutr. 2 (1982) 371-418

[14] Le Cozler Y., Beaumal V., David C., Neil M., Dourmad J.Y., Effect of feeding level during rearing on performance of Large White gilts. Part 1: growth, reproductive performance and feed intake during lactation, Reprod. Nutr. Dev. (1998).

[15] McNamara J.P., Lipid metabolism in adipose tissue during lactation: a model of a metabolic control system, J. Nutr. 124 (1994) 1383S-1391S.

[16] Neil M., Ad libitum lactation feeding of sows introduced immediately before, at, or after farrowing, Anim. Sci. 63 (1996) 497-505.

[17] Noblet J., Etienne M., Metabolic utilization of energy and maintenance requirements in lactating sows, J. Anim. Sci. 64 (1987) 774-781.

[18] Père M.C., Dourmad J.Y., Etienne M., Variation du débit sanguin utérin au cours de la gestation chez la truie, J. Rech. Porcine en France 28 (1996) 371-378.

[19] Prunier A., Martin C., Mounier A.M., Bonneau M., Metabolic and endocrine changes associated with undernutrition in the peripubertal gilt, J. Anim. Sci. 71 (1993) 1887-1894.

[20] Reese D.E., Peo E.R., Lewis A.J., Relationship of lactation energy intake and occurrence of post-weaning estrus to body and backfat composition in sows, J. Anim. Sci. 58 (1984) 1236-1244.

[21] SAS, SAS user's guide, Version 6.11, SAS Institute Inc., Cary, NC, 1996.

[22] Schams D., Kraetzl W.D., Brem G., Graf F., Secretory pattern of metabolic hormones in the lactating sow, Exp. Clin. Endocrinol. 102 (1994) $439-447$.

[23] Scheaffer A.L., Tong A.K.W., Sather A.P., Beltranena E., Pherazyn A., Aherne F.X., Periparturient diabetogenesis in primiparous gilts, Can. J. Anim. Sci. 71 (1991) 69-77.

[24] Shuster L.T., Go V.L.W., Rizza R.A., O’Brien P.C., Service F.J., Potential Incretins, Mayo Clin. Proc. 63 (1988) 794-800.

[25] Trottier N.L., Easter R.A., Dietary and plasma branched-chain amino acids in relation to tryptophan: effect on voluntary feed intake and lactation metabolism in the primiparous sow, $\mathbf{J}$. Anim. Sci. 73 (1995) 1086-1092.

[26] Van Milgen J., Berger L.L., Murphy M.R., Fractionation of substrate as an intrinsic characteristic of feedstuffs fed to ruminant, J. Dairy Sci. 75 (1992) 124-131.

[27] Weldon W.C., Lewis A.J., Louis G.F., Kovar J.L., Miller P.S., Postpartum hypophagia in primiparous sows: II. Effect of feeding level during gestation and exogenous insulin on lactation feed intake, glucose tolerance, and epinephrinestimulated release of non-esterified fatty acids and glucose, J. Anim. Sci. 72 (1994) 395-403.

[28] Whittemore C.T., Nutrition reproduction interactions in primiparous sows, Livest. Prod. Sci. 46 (1996) 65-83.

[29] Xue J.L, Koketsu Y., Dial G.D., Pettigrew J., Sower A., Glucose tolerance, luteinizing hormone release, and reproductive performance of first-litter sows fed two levels of energy during gestation, J. Anim. Sci. 75 (1997) 1845-1852. 